\title{
Insurance-based risk-sharing agreements
}

\author{
Augustin Terlinden ${ }^{1 *}$, Amine Aissaoui ${ }^{2}$, Olivier Ethgen ${ }^{3}$ \\ From 3rd International PPRI Conference 2015: Pharmaceutical Pricing and Reimbursement Policies: Chal- \\ lenges Beyond the Financial Crisis \\ Vienna, Austria. 12-13 October 2015
}

Stretched healthcare budgets have been tensing up patient access negotiations between healthcare payers and manufacturers. Data and the associated evidence available at registration are often deemed insufficient to accurately estimate the real-life clinical outcomes and budget impact. Payers want to reduce budget uncertainty and manufacturers need to evolve in a competing healthcare environment.

Risk-sharing agreements (RSAs) are on the rising trend. Conceptually, RSAs have the remarkable advantage of reducing payer exposure to the financial risks associated with the introduction of a new healthcare intervention. However, engaging in a RSA should be cautiously thought through and planned as those contracts entail important financial implications, notably for the manufacturer. Monitoring costs are elevated and might jeopardize the implementation [1].

Nowadays, most of the current RSAs tend to shift the uncertainty around an expected outcome from the healthcare payer to the manufacturers. Although one cannot refer to risk-sharing per se, manufacturers use it during negotiations as an alternative to price reduction [2].

We will define the insurance approach in the staggered financial evaluation of a potential RSA. The risk
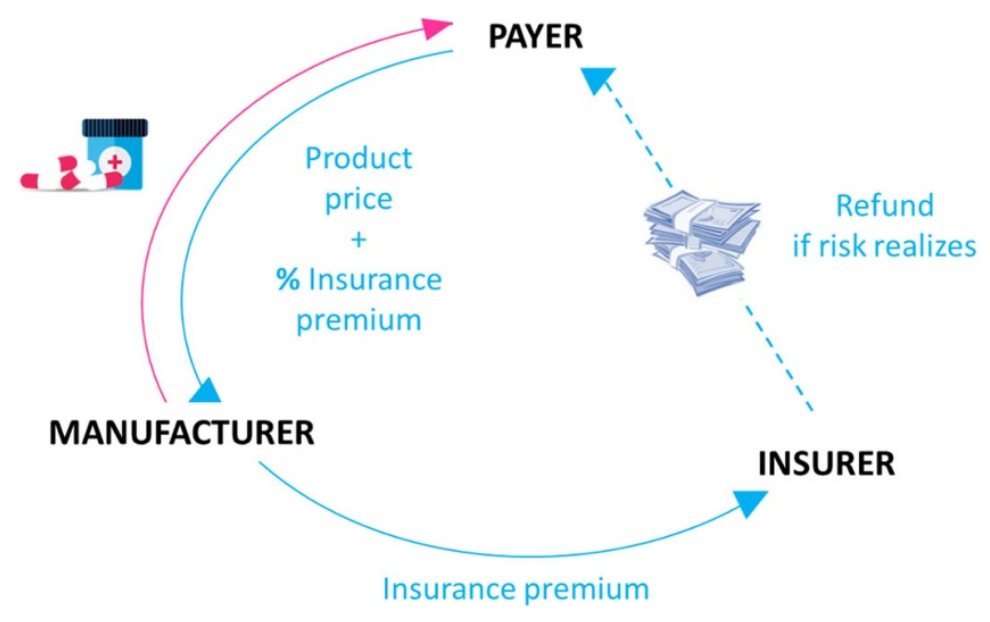

Figure 1 The risk embedded in healthcare contract did not simply shift from the payer to the manufacturer. An insurer stands behind the manufacturer. It reimburses the payer if the risk realizes

* Correspondence: augustin@blueantidote.com

'Blue Antidote, Brussels, 1050, Belgium

Full list of author information is available at the end of the article

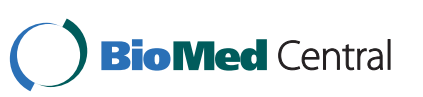

(c) 2015 Terlinden et al. This is an Open Access article distributed under the terms of the Creative Commons Attribution License (http:// creativecommons.org/licenses/by/4.0), which permits unrestricted use, distribution, and reproduction in any medium, provided the original work is properly cited. The Creative Commons Public Domain Dedication waiver (http://creativecommons.org/publicdomain/ zero/1.0/) applies to the data made available in this article, unless otherwise stated. 


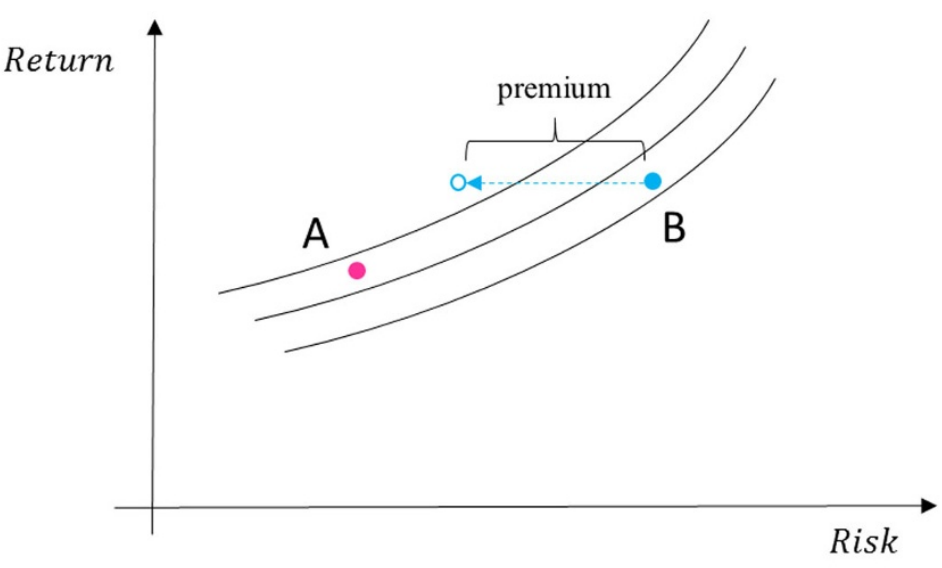

Figure 2 When packaged with an insurance contract, treatment B is preferred to treatment A.

will be quantified from the point of view of three professional risk-takers (i.e. an investment bank, a reinsurer and a pension fund) willing to insure the transaction (Figure 1). Various formulas to split this risk-equivalent cost (i.e. insurance premium) between a manufacturer and a payer will be proposed (Figure 2). Budget gains for switching from the actual situation to the three riskequivalent costs methodologies will be illustrated using a fictive oncology product.

\section{Authors' details}

'Blue Antidote, Brussels, 1050, Belgium. ${ }^{2}$ Paris Dauphine University, Paris, 75016, France. ${ }^{3}$ University of Liège, Liège, 4000, Belgium.

Published: 5 October 2015

\section{References}

1. Ethgen $\mathrm{O}$, Terlinden $\mathrm{A}$ : Warranting budget predictability through managed entry agreements and insurance-based mechanisms. ISPOR 20th Annual International Congress. Philadelphia. USA; 2015.

2. Ethgen $\mathrm{O}$, Terlinden A: Evaluation of risk-sharing agreements: a real option approach. ISPOR 17th Annual European Congress. Amsterdam. The Netherlands; 2014.
Submit your next manuscript to BioMed Central and take full advantage of:

- Convenient online submission

- Thorough peer review

- No space constraints or color figure charges

- Immediate publication on acceptance

- Inclusion in PubMed, CAS, Scopus and Google Scholar

- Research which is freely available for redistribution

Submit your manuscript at www.biomedcentral.com/submit 